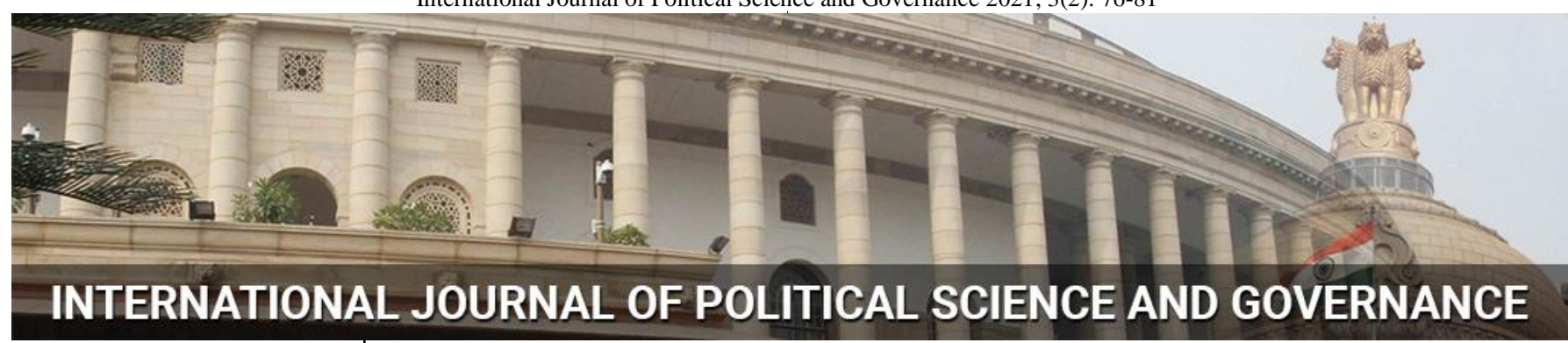

E-ISSN: 2664-603X P-ISSN: 2664-6021 IJPSG 2021; 3(2): 76-81 www.journalofpoliticalscience.com Received: 10-08-2021 Accepted: 15-09-2021

\section{Monika Gupta}

Research Scholar, Centre for European Studies, School of International Studies,

Jawaharlal Nehru University, New Delhi, Delhi, India
Corresponding Author: Monika Gupta

Research Scholar, Centre for European Studies, School of International Studies,

Jawaharlal Nehru University, New Delhi, Delhi, India

\section{Women rights as human rights: Comparative study of India and Pakistan}

\section{Monika Gupta}

DOI: https://doi.org/10.33545/26646021.2021.v3.i2b.111

\begin{abstract}
Human Rights are fundamental basic rights that form the very existence of the human beings from the day they are born until their death. Without these basic human rights, there existence and survival will be at stake. The need to look at Human Rights from a gender perspective arises from the very fact that women over the years have been subordinated in history and have been considered inferior to men and hence the phrase "Women Rights as Human Rights" have garnered world attention with countries across the world adopting policies prioritising women rights. Today, the world of academia discusses and deliberates upon the urgent need to protect women rights from the shackles of deep-rooted patriarchal system. In the above context, this paper intends to discuss women rights as human rights in the context of two prominent countries of South Asia- India and Pakistan. The first part of the paper provides a general understanding of human rights and women rights. The second part throws light upon international developments related to human and women rights and how they have formed the basis of future recourse. The third and most important part of the paper makes a comparative understanding about the situation of women rights in India and Pakistan and how the two countries are largely different when it comes to protecting the women rights irrespective of both countries being the democracies. The last and final section of the paper shall discuss necessary findings and apt conclusions.
\end{abstract}

Keywords: India, Pakistan, women rights, human rights, South Asia, laws

\section{Introduction}

Women Rights are Human Rights is a proverb that is often used broadly in the field of Academia and International Relations. The need to look at Human Rights from a gender perspective arises from the very fact that women over the years have been subordinated in history and have been considered inferior to men. Their subjugation and exploitation by the system itself creates a gap in the existing research on Women Rights as Human Rights. Hence, the purpose of the article revolves around addressing women rights in greater details in the context of India and Pakistan.

The title of the paper incorporates two major countries of South Asia-India and Pakistan. The purpose of taking these two countries involves various reasons and perspectives- some of the major being- Both countries share a long history, have common colonial past, became independent at the same time and have always been two major conflicting neighbours at the world stage. India and Pakistan are two countries that have rarely shared a harmonious relationship owing to an array of reasons and any talks, summit or diplomatic efforts have majorly failed in the past to bring the two countries at peace with one another. The reasons behind the conflict between the two nations are however, not within the scope of this paper. This paper reflects upon the fact that despite having many similarities, the two countries have evolved themselves differently in different ways- for instance; the two countries are wide apart in terms of governance, role of military, societal structures and obviously in terms of role and involvement of women within their respective societies.

This role and involvement of women within the society brings to the forefront the issue of women rights and to what extent they are considered as Human Rights in the two respective countries. In this regard, this paper has been divided into various sub-parts for proper understanding of the situation and for an effective analytical comparative understanding. 
The first part of the paper talks about basic Human rights and Women rights in general. The second part of the paper tends to include international perspectives on women rights and human rights which will help us to visualise the comparative study between India and Pakistan in a more lucid way. The third and the most important part of the paper talks about the situation of women rights and how they are perceived within the two countries of India and Pakistan wherein there shall be a flow from the past until the present. The last and final part of the paper shall discuss necessary findings and apt conclusion.

\section{Human rights and women rights}

This section provides us with a more general understanding of the concepts of human rights and women rights. Human Rights are fundamental basic rights that form the very existence of the human beings from the day they are born until their death. Without these basic human rights, there existence and survival will be at stake. These rights belong to them irrespective of their place of birth, place of living, religion, class, ideology, sex or any other factor. These basic human rights have a much wider connotation and it includes right to life, right to live with dignity, right to food, right to clean water and sanitation, right to education, right to express and many such similar rights (Equality and Human Rights Commission 2019) ${ }^{[3]}$.

The very basic premises on which these human rights are based include respect, dignity, fairness, independence etc. and these values are inherently protected by the rule of law in a particular country. In most of the democracies of the world, these values and rights are more pronounced and have been given a higher pedestal as compared to the undemocratic countries where rights and values are not much talked about and this is the reason that the most successful and developed economies of the world are democracies that value human rights of their citizens.

In a similar context of Human rights, the term 'women rights' sprung years back that exclusively talk about the rights of women. The first question that strikes us is 'why women rights?' or why not 'men rights' or what is the whole purpose of isolating women rights from a wider concept of 'human rights'? This question has troubled academicians and researchers over the years and the inherent reason why it is important to talk about 'women rights' exclusively lays in the years of oppression and subjugation of women at the hands of men within a welldeveloped and flourishing 'patriarchal system'.

This system of patriarchy can be found in every corner of the world irrespective of a developed or an underdeveloped country. This system of patriarchy involves excessive control and domination of men over women which results into women being the victims of this social disorder and as a result being denied their basic human rights. This system of patriarchy is deeply-rooted within our system and Walby (1989) ${ }^{[14]}$ defines six particular ways and sources from which it emerges and adversely affects women in the contemporary times. These six sources include the following- Paid Work where women are differentiated at work place against men in terms of wages or promotions; Housework which is considered as women-centric and is unpaid and deeply exploited by men; Culture which reinforces gender norms and values and places men at the pedestal and in some culture gives them the control over women's lives; Sexuality which includes different sexual behaviours and expectations for men and women and hence result into discrimination and differential treatment; Violence is another major source of patriarchy where men feel that they can control and dominate women through exerting physical force; and lastly the sixth source The role of State which Walby believes has changed over the years but we still find issues like lesser representation of women in politics or in decision-making where State has to play a predominant role (Walby 1989) ${ }^{[14]}$.

From the above framework, it becomes important to understand the need for exclusively talking about women rights as human rights and what can be done if it stands violated. In this context, let us first understand the importance of women rights from the perspective of international organisations and institutions.

\section{International Perspectives on Women Rights as Human Rights}

This section highlights the contributions, role and significance of major international developments in promoting and protecting basic women rights which are fundamental to their existence and which if denied can be considered as a serious violation of human rights.

In the aftermath of the Second World War, the United Nations Charter of 1945 inherently adopted the principle of fundamental human rights and advocated for equal rights for both men and women (Preamble, United Nations Charter 1945) ${ }^{[8]}$. Since then, human rights have formed a fundamental pillar of future organisations and institutions and have played a significant role in their working. Every country has framed their own legislations pertaining to human rights. However, there have been certain dominant events in history that have since motivated the countries of the world to look up to them while framing their internal laws and regulations. Some of these landmark documents in the field of human rights include- The Magna Carta of 1215, the Bill of Rights 1689, the French Declaration on the Rights of Man and Citizen 1789, The US Constitution and Bill of Rights 1791. These have been the pre-cursors to the modern framing of human rights (Sutto 2019) ${ }^{[12]}$.

With the base of these landmark documents, evolved the modern landmark achievement of the United Nations in the form of The Universal Declaration of Human Rights (UDHR) 1948 which was signed by more than fifty member states who prioritised human rights and ensured its protection especially after the dreadful scenes of the Second World War. Since 1948, many subsequent acts and legislations came globally including the European Convention of Human Rights 1950, the Human Rights Act 1998 etc.

With human rights in place, women rights exclusively were never talked about in these historic and landmark declarations. "Women's Rights are Human Rights" is the phrase that was predominately used in the 1980s and early 1990s during the feminist movement. However, it's most prominent usage was made during the speech of Hillary Clinton, the First lady of the United States in the year 1995 when she was addressing the UN's Fourth World Conference on Women in Beijing, China. She said, "If there is one message that echoes forth from this conference, let it be that human rights are women's rights and women's rights are human rights, once and for all". She continued saying that "As long as discrimination and inequities remain so commonplace everywhere in the world, as long as girls and 
women are valued less, fed less, fed last, overworked, underpaid, not schooled, subjected to violence in and outside their homes - the potential of the human family to create a peaceful, prosperous world will not be realized" (Washington Week 1995) ${ }^{[15]}$.

This historic speech had such a profound impact on the feminist movements across the world and it was made clear that one needs to exclusively address the issue of women rights and that it calls for the attention of the world to take this as one of their priorities while framing any laws or regulations. Women rights exclusively implies all those rights that a woman should have irrespective of her gender and against which she has been facing years of discrimination, for instance, right to live free from violence, slavery and discrimination; right to be educated; right to own property; right to vote; right to earn a free and equal wage and many such similar rights (Global Fund for Women 2021) ${ }^{[4]}$.

Looking at the developments in the last two decades, the world has moved from MDGs to SDGs (Millennium Development Goals to Sustainable Development Goals) with both targets focussing exclusively on gender equality and women's rights. However, despite global efforts, it has been observed that many countries have failed to recognise women's rights or give them the due place within their national and local policies. There are still instances of gender-based violence happening all around the world including cases of female genital mutilation, harassment at work place, unfair wages, domestic violence, rape etc.

In the above context, this paper focuses upon the situation of women rights in the two countries of India and Pakistan. Both these countries as mentioned above have many things in common until partition divided them but since their independence, both these countries have taken diverse developmental approaches and hence it becomes important to understand the situation of human rights from a gendered perspective in these two countries of India and Pakistan.

\section{Comparative understanding of Women Rights in India and Pakistan}

To begin understanding the human rights situation in these two countries, it is important to first understand the basic structure of their governance. Both these two countries are democracies and both of them have adopted and framed their own constitution. Both these countries also have special provisions for human rights in the form of fundamental rights enshrined within their constitution. And these basic rights include freedom of speech, thought, expression, press etc. This is common to both the countries. Despite such similarities in governance, there are striking differences between the two countries when it comes to application of human rights or women rights or basic rights of individuals. This paper exclusively talks about women rights in the two countries.

India: India since independence has greatly transformed itself in terms of advocating equal rights for both men and women. Indian constitution and various legislations exclusively guarantee women rights and offer severe punishments in case of violation. It is beyond any doubt that India is still under the garb of patriarchy but it is equally true that the hold of patriarchy over women is becoming fluid with every generation. It is to be appreciated that India has been successful to a great extent in reducing various forms of social evils targeted against women like child marriage, Sati, female infanticide etc. if not completely eliminating them.

India has witnessed various feminist movements that have strongly raised their voices and concerns regarding women rights and how different forms of violence are a threat to those basic rights. The Indian constitution through Fundamental Rights (Article 14, 15, 19, 21) and Directive Principles (Article 51-A, 42, 39) ensures and protects women's dignity and rights both inside and outside their homes. The free and independent India believed in the freedom of women from the shackles of deep-rooted patriarchy. Today, women in India today enjoy various basic human rights and these include right to equal pay, right to dignity and decency, right against workplace harassment, right against domestic violence, right to free legal aid, right against indecent representation, right to zero FIR and many more such rights which protects a woman's integrity and dignity (India Today 2016) ${ }^{[5]}$.

Despite such provisions in place, violence against women continues to exist even until now. There still exists range of areas where human rights violations still take place for instance in issues related to dowry, preference for son, female foeticide, domestic violence, forced evictions etc. (Saryal 2014) ${ }^{[9]}$. The main reason behind this is the existence of patriarchy in different forms and which has made women vulnerable at the hands of men. In the Global Gender Gap Index of 2021 published by World Economic Forum, India slipped by 28 positions and landed at 140 out of 156 countries worldwide (Business Standard 2021) ${ }^{[5]}$. This data is definitely shocking but the main reason for India to fall to this low rank lays behind lesser representation and participation of women in the workforce with maximum decline on the "Political Empowerment" sub-index. Apart from this, share of women in technical and professional roles declined to $29.2 \%$ whereas senior and managerial positions are held by just $14.6 \%$ women in India (Scroll 2021) ${ }^{[10]}$. This data is an indication of the fact that it's high time that women should be involved within the political mainstream and their labour force participation rate should drastically increase and this can only happen with the support of the government, civil society and individuals together.

However, despite such situation in India, it has also been observed that women in India are becoming more selfreliant and confident in terms of standing for their rights. The strict boundary of patriarchal influence is getting fluid and there are many men who are also standing up for the women's rights in India. India also recently gave equal inheritance rights to women and girls within the family along with men by amending the Hindu Succession Act of 1956. This law takes into consideration the rights of Hindu women along with Buddhists, Sikhs, and Jains, followers of AryaSamaj and BrahmoSamaj who are also considered as Hindus for the purpose of this right (Vishwanath 2020) ${ }^{[13]}$. This is considered as a landmark judgement in granting ancestral inheritance rights to Hindu women along with men within the families. Such a judgement delivered in 2020 comes after decades of struggle and fight for equality.

Similarly, allowing for reservations of one-third women at village-level governance has yielded better results with rural women becoming more confident and that sense of representation has led to a decrease in the number of cases of violence against them or simultaneously more number of 
cases are being reported now. It has been found that villages led by women have more confident female residents as their choices and preferences are better represented and they feel confident in reporting crimes which was earlier considered as stigmatising to their identity and honour of their families (Sharma 2016) $^{[11]}$.

It has also been observed that there is an increase in the age of marriage and childbearing for women, particularly in rural India. Earlier it was prevalent that a woman had many children owing to factors like sustaining livelihood as more hands mean more income but this rate has gone down which has positively affected both the mental and physical lives of women in rural areas (Sharma 2016) ${ }^{[11]}$. At the same time, there is an increase in more number of young girls going to school owing to factors like government schemes and interventions, mid-day meal and aspirations among the parents to see their children educated including the girl child. All these changes, though slow, have positively changed the scenario of women rights in India where both women and her family are equally sensitive towards women rights.

Thus, it can be said that despite the existing problems and issues in India, there is a new wave of girls and women who are not only aware about their rights but also are ready to take actions in case of any violation or discrimination of their rights and they will no longer tolerate any form of subjugation inflicted upon them either by the male counterparts or by the system itself. Thus, this focuses greatly on the present status of women rights in India and how things are changing for the better over the years.

Pakistan: Pakistan which was born in the year 1947 after India's partition adopted a completely different model of governance despite being called a democracy. And this is the reason that there exists a stark difference in the model of their human rights as compared to India. When it comes to women in Pakistan, it won't be wrong to say that there hasn't been any major feminist movement in the history of Pakistan. Also, the relationship between Pakistani government and women has been mediated through a group of elite men and women who have access to state institutions and services on a priority basis (Kirmani 2000) [6]. Kirmani further writes that discussing about 'women' in Pakistan is itself problematic as this entire discussion on women rights is greatly influenced by factors like sharp class distinctions, religious and ethnic differences etc. Thus, the first major contrast that exists between India and Pakistan is in terms of women being able to voice their concerns directly with the state institutions and that they are given the freedom to do the same which seems restricted within the territory of Pakistan.

Considering the constitutional provisions in place for women in Pakistan, the constitution of Pakistan came up in the year 1973, long after its formation in 1947. The constitution does guarantee fundamental rights to its citizens (Sections 8- 28) and ensure that there is no discrimination on the basis of 'sex' of a person, thereby promoting gender equality (Muneer 2017) ${ }^{[7]}$. However, the implementation and reality on the ground appears different and these basic fundamental rights come with restrictions towards minorities in Pakistan and there continues to exist different kinds of violence against women. Despite the constitutional provisions, there are various other legislations that exclusively guarantee and protect women rights like Muslim
Personal Law of Sharia, Muslim Family Law Ordinance, Women's Protection Bill and many more but all these legislations severely failed when it comes to implementation and execution.

The above situation of women rights in Pakistan can also be understood in the light of the recent Global Gender Gap Index 2021 published by World Economic Forum in which Pakistan ranks 153 out of 156 countries globally (Business Standard 2021) ${ }^{[5]}$. The position of Pakistan on a world scale in promoting gender equality is low despite the Prime Minister Imran Khan's assertion of their working towards gender equality. According to this report, women participation in the labour force stands at $22.6 \%$, while only $4.6 \%$ are at managerial levels. There also exists huge income disparities between men and women and a Pakistani woman's income is just $16.3 \%$ of that of a man. The report also highlights that Pakistani woman do not have equal access to justice, inheritance rights, ownership of land etc. Also the literacy rate among women stands at $46.5 \%$ among which $61.6 \%$ attend primary school, $34.2 \%$ attend high school and a mere $8.3 \%$ are enrolled in tertiary education courses (Wion 2021) ${ }^{[16]}$.

Thus, the above data is the reflection of the fact that position of women within the territory of Pakistan stands marginalised and neglected. Women rights as basic human rights exist only on paper while the reality on the ground is still very different (Muneer 2017) ${ }^{[7]}$.

Pakistan even today is under the rigid garb of patriarchy where decision making is male-centric within the family and there is little or no-involvement of women in it. Muneer (2017) [7] says that the dominating and overwhelming behaviour of males within the family consider their women as living on their mercy since women are dependent on them economically and socially because of which the male feels that they are superior to women and can dominate them in any way they want which indirectly jeopardises the implementation of existing legislations that protect women. Somewhere the Pakistani women themselves have accepted this way of living and in some cases they are even not aware that their basic rights are abridged. Another major hurdle in the way of women rights in Pakistan is the fact that girls there are still married at a very young age where they are not only immature but also vulnerable and weak and live at the mercy of their husbands.

The role of media in Pakistan is extremely important when it comes to women rights and human rights. This is so because media in Pakistan is extremely insensitive towards women issues and they hardly portray any gender sensitive issues in either electronic or print media. The main reason behind this is the fact that media industry and its decisionmaking rests with the men more as compared to females and hence media in Pakistan drastically fails to raise awareness or highlight any issue related to women empowerment or their development (Muneer 2017) ${ }^{[7]}$. This shows not only the conservativeness prevalent within the Pakistani society but also reflects their narrow-mindedness when it comes to their women and their basic rights and this is perhaps the reason that even after more than seventy years of its formation, it has utterly failed to prioritise women issues within its national policies.

The state of women rights is reflected from the fact that when women led a procession in Islamabad on $8^{\text {th }}$ March 2020 on account of International Women's Day and gave slogans like "My Body, My choice" as a mark of protest to 
come out from the tyranny of men, the PM of Pakistan Imran Khan completely denying the purpose of the procession, made a statement saying that the reference to word "body" in the slogan offended Islamic edicts and that indirectly it shouldn't have been said (Ahmed 2020). Thus, one can easily get a glimpse of the $21^{\text {st }}$ century Pakistani and the condition of women therein.

\section{Conclusion}

This paper tried reflecting at some of the pertinent issues related to women in the $21^{\text {st }}$ century by doing a comparative case-study of India and Pakistan. The article highlights and discusses important concepts like women rights, human rights and their relevance when it comes to a gender-equal world. It has been observed that despite repeated global efforts to address the issue of gender violence, there continues to exist gross human rights violations, particularly women rights.

In terms of comparative understanding of women rights in India and Pakistan, it has been observed that patriarchy holds a significant position in both the societies and women are still witnessing some or the other forms of violence which is inflicted upon them through their male counterparts. However, in the case of India, this strict and rigid boundary of patriarchy seems to become fluid where women are becoming more expressive and are more aware about their rights whereas in the case of Pakistan, women are still denied their basic freedom to express. In the case of India, it has been seen that how there have been constant efforts of negotiation between the government and the women whereas this severely lacks in Pakistan owing to extreme conservativeness and narrow-mindedness both within the society and at the level of governance and administration.

Both India and Pakistan are democracies at world stage, but their functioning of democracies are hugely different and which in turn has an impact upon their women. In India, one can see the rise of powerful feminists and strong feminist movements where women have come forward and raised their concerns over their rights. However, such feminine voices are strongly resented in Pakistan owing to factors like strong hold of Islam as a religion which propagates male superiority. Today, India has witnessed strong and powerful female voices in almost every sector from economic, political to science, administration etc. but such strong representation lacks when it comes to Pakistan.

Thus, these hostile neighbours who although started their journey as an independent country at the same time, have widely adopted different paths when it comes to governance, administration and justice delivery systems and this perhaps has hugely affected the evolution of human rights. While Indian societal structure adapted with the change in time, Pakistan's society still continues to grow under the garb of conservativeness which in turn has proved detrimental to women rights.

\section{References}

1. Ahmed K. In $21^{\text {st }}$ century Pakistan, women continue to be denied agency rights, The Indian Express 2020. Available online, Accessed on 10 July 2021, URL: https://indianexpress.com/article/opinion/columns/aurat -march-pakistan-women-rights-freedom-empowermentinternational-womens-day-imran-khan/.

2. Business Standard. WEF's Gender Gap Index: India slips 28 places, ranks 140 among 156 nations 2021. Available online, Accessed 5 July 2021, URL: https://www.business-standard.com/article/currentaffairs/wef-s-gender-gap-index-india-slips-28-placesranks-140-among-156-nations-121040100015_1.html.

3. Equality and Human Rights Commission. What are Human Rights 2019. available online, Accessed 10 July 2021,

https://www.equalityhumanrights.com/en/humanrights/what-are-human-rights

4. Global Fund for Women. What are women's human rights 2021. available online, Accessed on $9^{\text {th }}$ July 2021,URL:

https://www.globalfundforwomen.org/womens-humanrights/?tclid=

5. India Today. 11 exclusive rights for women every Indian needs to know 2016. available online, 8 March, Accessed on 7 July 2021, URL: https://www.indiatoday.in/education-today/gk-currentaffairs/story/11-women-rights-india-312263-2016-0308.

6. Kirmani Nida. Women's Rights as Human Rights: The case of Pakistan, Senior Thesis Projects, 1993-2002, available online 2000. Accessed 8 July 2021, URL: https://trace.tennessee.edu/cgi/viewcontent.cgi?referer= https://www.google.com/\&httpsredir=1\&article=1046\& context=utk_interstp2.

7. Muneer S. Pro-woman laws in Pakistan: Challenges towards Implementation, Journal of Pakistan Vision 2017;18(2):86-101.

8. Preamble. United Nations Charter, available online 1945. Accessed 5 July 2021, URL: https://www.un.org/en/about-us/un-charter/full-text.

9. Saryal S. Women's Rights in India: Problems and Prospects, International Research Journal of Social Sciences 2014;3(7):49-53.

10. Scroll. India falls 28 spots on 2021 Global Gender Gap Index to $140^{\text {th }}$ Rank, 31 March, available online 2021. Accessed on 6 July 2021, URL: https://scroll.in/latest/991074/india-falls-28-spots-on2021-global-gender-gap-index-to-140th-rank.

11. Sharma S. Achieving Gender Equality in India: What works and what doesn't, United Nations University 2016. available online, Accessed 7 July 2021, URL: https://unu.edu/publications/articles/achieving-genderequality-in-india-what-works-and-what-doesnt.html.

12. Sutto M. Human Rights Evolution, A Brief History, The CoESPU Magazine 2019;3:18. doi: 10.32048/Coespumagazine3.19.3.

13. Vishawanath A. Explained: Reading SC's verdict on Hindu Women's inheritance rights, The Indian Express, available online 2020. Accessed 7 July 2021, URL: https://indianexpress.com/article/explained/readingsupreme-court-verdict-on-hindu-womens-inheritancerights-6550767/.

14. Walby S. Theorising Patriarchy, Sociology 1989;23(2):213-234, Doi$10.1177 / 0038038589023002004$.

15. Washington Week. Hillary Clinton declares Women's Rights are Human Rights, available online 1995. Accessed $\quad 9^{\text {th }}$ July 2021, URL: https://www.pbs.org/weta/washingtonweek/webvideo/hillary-clinton-declares-womens-rights-arehuman-rights. 
16. Wion. Pakistan ranks $153^{\text {rd }}$ out of 156 countries on gender inequality, 31 March, Wion Web Team, available online 2021. Accessed 9 July 2021, URL: https://www.wionews.com/south-asia/pakistan-ranks153rd-out-of-156-countries-on-gender-inequality374608 . 